\title{
Pemanfaatan Data Rekam Medis dalam Pelaporan Bulanan di Puskesmas Kejaksan Cirebon
}

\section{Utilization Of Medical Record Data in Monthly Reporting at Public Health Center Kejaksan Cirebon}

\author{
Sri Nurcahyati ${ }^{1}$, Nimas Dewi Lestari ${ }^{1}$ \\ 1,2 STIKes Mahardika \\ Jl. Terusan Sekarkemuning No. 199 Karya Mulya Evakuasi Cirebon 45135 \\ *e-mail korespondensi: $\underline{\text { srinur@stikesmahardika.ac.id }}$
}

\begin{abstract}
Abstrak
Rekam medis merupakan berkas yang berisikan catatan dan dokumen tentang pasien, pemeriksaan, pengobatan, tindakan dan pelayanan lain yang telah diberikan pada pasien. Pembuatan rekam medis bertujuan untuk mendapatkan data dari pasien mengenai riwayat kesehatan, riwayat penyakit dan pengobatan yang telah diberikan kepada pasien sebagai upaya peningkatan pelayanan kesehatan. Tujuan penelitian yaitu utuk mengetahui pemanfaatan data rekam medis dalam pelaporan bulanan di Puskesmas Kejaksan Cirebon. Jenis penelitian adalah deskriptif dengan menggunakan observasi. Cara pengumpulan data dilakukan dengan observasi dan wawancara. Objek yang digunakan dalam penelitian ini adalah data rekam medis di puskesmas Kejaksan Cirebon. Hasil penelitian menunjukan bahwa data rekam medis meliputi data administratif dan data klinis, jenis laporan yang ada di puskesmas terdiri dari data rutin dan tidak rutin. Data rutin meliputi laporan mingguan, bulanan dan tahunan. Data tidak rutin meliputi laporan kejadian luar biasa dan laporan khusus sentinel. Serta pemanfaatan data rekam medis digunakan untuk laporan bulanan, yaitu LB1 (laporan data kesakitan, LB3 (tentang KIA dan KB) serta LB4 (tentang kegiatan puskesmas).
\end{abstract}

Kata kunci: Pemanfaatan, Data rekam medis, Puskesmas, Laporan bulanan

\begin{abstract}
Medical records are files containing records and documents about patients, examinations, treatments, actions and other services that have been provided to patients. Making medical records aims to obtain data from patients regarding medical history, medical history and medication that has been given to patients in an effort to improve health services. The purpose of the study was to determine the utilization of medical record data in monthly reporting at Public Health Center Kejaksan Cirebon. This type of research is descriptive using observation. The method of data collection is done by observation and interviews. The object used in this study is medical record data at Public Health Center Kejaksan Cirebon. The results showed that the medical record data includes administrative data and clinical data, the types of reports in the Public Health Center consist of routine and nonroutine data. Routine data includes weekly, monthly and yearly reports. Non-routine data include extraordinary event reports and sentinel special reports. As well as the utilization of medical record data used for monthly reports, namely LB1 (reports on pain data, LB3 (about health of both mother and child and family planning) and LB4 (about Public Health Center activities).
\end{abstract}

Keywords: Utilization, Medical record data, Public health, Reporting monthly

\section{PENDAHULUAN}

Rekam medis merupakan berkas yang berisikan catatan dan dokumen tentang identitas pasien, pemeriksaan, pengobatan, tindakan dan pelayanan lain yang telah diberikan kepada pasien. Catatan merupakan tulisan yang dibuat oleh dokter dan dokter gigi mengenai tindakan yang diberikan kepada pasien saat dokter memberikan pelayanan kesehatan. Dokumen merupakan catatan dokter, dokter gigi, dan petugas kesehatan tertentu, laporan hasil 
pemeriksaan penunjang, catatan observasi dan pengobatan harian dan semua rekaman (Permenkes 269, 2008).

Catatan dalam rekam medis sangat berguna untuk dokter agar dapat mengingat kembali akan hasil pemeriksaan dan pengobatan yang telah diberikan bila pasien datang kembali untuk berobat ulang. Setiap sarana pelayanan kesehatan baik rumah sakit maupun puskesmas wajib membuat rekam medis. Sehingga dapat diartikan rekam medis besar pengaruhnya terhadap kualitas pelayanan kesehatan yang diberikan untuk pasien, juga menyumbangkan hal yang penting digunakan di hukum kesehatan. Rekam medis dapat digunakan sebagai bahan pendidikan, penelitian, dan akreditasi (Gunarti dan Muchtar, 2019).

Pembuatan rekam medis bertujuan untuk mendapatkan data dari pasien mengenai riwayat kesehatan, riwayat penyakit dan pengobatan yang telah diberikan kepada pasien sebagai upaya peningkatan pelayanan kesehatan. Setiap dokter, dokter gigi, tenaga kesehatan tertentu, petugas pengelola, dan pimpinan sarana pelayanan kesehatan harus menjaga informasi tentang identitas, diagnosis, riwayat penyakit, riwayat pemeriksaan, dan riwayat pengobatan pasien. Pimpinan sarana kesehatan bertanggung jawab atas hilang, rusak, pemalsuan dan atau penggunaan oleh orang atau badan yang tidak berhak terhadap rekam medis (Gemala, 2014).

Kegunaan rekam medis juga dapat dilihat dari dua kelompok besar yakni kegunaan utama dan kegunaan sekunder. Kegunaan utama rekam medis berkaitan langsung dengan pasien, meliputi kepentingan pasien, kepentingan pelayanan pasien, kepentingan manajemen pelayanan, kepentingan penunjang pelayanan, dan kepentingan pembiayaan. kegunaan sekunder rekam medis ditunjukan kepada hal yang berkaitan dengan lingkungan seputar pelayanan pasien yakni edukasi, peraturan, riset, pengambilan kebijakan, dan industri (Gunarti dan Muchtar, 2019). Sehingga dapat diartikan rekam medis erat kaitannya dengan pelaporan, yang mana setiap unit harus melaporkan kegiatan yang dilaksanakannya.

Setiap kepala Puskesmas harus menyampaikan laporan kegiatan Puskesmas secara berkala kepada Kepala Dinas Kesehatan Kabupaten/Kota yang disususn berdasarkan pencatatan kegiatan dan hasil kegiatan di Puskesmas dan jaringan Puskesmas (Permenkes 31, 2019). Kewajiban pembuatan laporan pada tingkat Puskesmas dikenal dengan Sistem
Pencatatan dan Pelaporan Terpadu Puskesmas (SP2TP). SP2TP dibuat dari pengumpulan sumber data yang meliputi kartu-kartu individu warga masyarakat di wilayah Pukesmas dan register masing-masing unit pelayanan. Laporan yang dibuat diantaranya Laporan Bulanan (LB1, LB2, LB3); Laporan Tahunan (LT1, LT2); Laporan Wabah (W1, W2); Laporan Bulanan Sentinel (LB1S, LB2S) yang dilaporkan setiap ada KLB, mingguan, bulanan dan tahunan (Budi, 2011).

Tujuan penelitian yaitu utuk mengetahui pemanfaatan data rekam medis dalam pelaporan bulanan di Puskesmas Kejaksan Cirebon.

\section{METODE PENELITIAN}

Jenis penelitian adalah deskriptif dengan menggunakan observasi Penelitian deskriptif yaitu penelitian yang berusaha mendeskripsikan suatu gejala, peristiwa, kejadian yang terjadi sekarang (Noor, 2017). Variabel penelitian merupakan suatu yang menjadi objek pengamatan penelitian, sering juga disebut sebagai faktor yang berperan dalam penelitian atau gejala yang akan diteliti (Hermawan, 2019). Variabel pada penelitian ini yaitu pemanfaatan data rekam medis yang meliputi Laporan Bulanan 1 (LB1), Laporan Bulanan 3 (LB3) dan Laporan Bulanan 4 (LB4) di Puskesmas Kejaksan Cirebon. Cara pengumpulan data dilakukan dengan observasi dan wawancara. Objek penelitian merupakan variabel yang diteliti (Anshori, 2017). Objek yang digunakan dalam penelitian ini adalah data rekam medis di puskesmas Kejaksan Cirebon serta subjek penelitian adalah petugas pelaporan dan kepala puskesmas. Instrumen dalam penelitian ini menggunakan lembar observasi dan pedoman wawancara.

\section{HASIL DAN PEMBAHASAN}

Rekam medis adalah berkas yang harus dibuat secara tertulis, lengkap dan jelas atau secara elektronik berisikan catatan dan dokumen tentang identitas pasien, pemeriksaan, pengobatan, tindakan dan pelayanan lain yang telah diberikan kepada pasien (Permenkes 269, 2008). Puskesmas merupakan fasilitas pelayanan kesehatan yang menyelenggarakan upaya kesehatan masyarakat dan upaya kesehatan perseorangan tingkat pertama, dengan lebih mengutamakan upaya promotif dan preventif 
untuk mencapai derajat kesehatan masyarakat yang setinggi-tingginya. Puskesmas dalam penyelenggaraannya memiliki sistem kesehatan guna membantu proses administrasi dan manajemen puskesmas (Permenkes No 75, 2014).

Puskesmas mempunyai tugas dan tanggung jawab terhadap pembangunan berwawasan kesehatan dengan konsep wilayah. Puskesmas berkoordinasi dengan lintas sektor untuk meningkatkan derajat kesehatan masyarakat (Anita, Febriawati dan Yandrizal, 2019). Unit rekam medis sebagai salah satu gerbang terdepan dalam pelayanan kesehatan pada fasilitas pelayanan kesehatan sangat berperan untuk memelihara dan menjaga rekam medis, dapat sebagai salah satu ukuran kepuasan pasien dalam menerima pelayanan (Budi, 2011).

Isi rekam medis dapat dibagi menjadi data administratif dan data klinis (Indradi, 2017):

1. Data administratif

Data administratif meliputi data demografi, keuangan dan data atau informasi lain yang berhubungan dengan pasien misalnya tentang pernyataan pasien untuk menerima atau menolak suatu rencana medis yang biasanya ditulis dan ditandatangani oleh pasien atau wali pada lembar informed consent, pernyataan pasien tentang pemberian hak kuasa dan juga pernyataan tentang kerahasiaan informasi medis.

Data demografi setidaknya mencakup informasi tentang:

1) Nama lengkap. Aturan penulisan nama lengkap ini disusun tersendiri dan menjadi acuan dalam penulisan nama lengkap pasien dalam lembar-lembar rekam medis.

2) Nomor rekam medis dan nomor identitas lainnya (misalnya nomor asuransi).

3) Alamat lengkap.

4) Tanggal lahir dan kota tempat kelahiran.

5) Jenis kelamin.

6) Status pernikahan.

7) Nama dan alamat keluarga terdekat yang sewaktu-waktu dapat dihubungi.

8) Tanggal dan waktu saat terdaftar di tempat penerimaan pasien rawat inap, rawat jalan atau gawat darurat.

9) Nama identitas lain dari sarana pelayanan kesehatan, misalnya rumah sakit (umumnya tercantum pada bagian atas formulir).

2. Data klinis
Data klinis dapat merupakan data yang diperoleh dari hasil pemeriksaan, pengobatan, perawatan, dan tindakan yang dilakukan oleh tenaga kesehatan dan penunjang medis terhadap pasien. Dari runtutan cerita dalam lembarlembar yang berisi data klinis inilah yang akan dapat diambil informasi untuk berbagai kebutuhan, terutama yang berkaitan langsung dengan pelayanan kepada pasien.

Kegiatan sistem pelaporan yang digunakan oleh puskesmas adalah melalui SP2TP. SP2TP (Sistem Pencatatan dan Pelaporan Terpadu Puskesmas) merupakan laporan yang dibuat puskesmas mengenai semua kegiatan puskesmas meliputi data umum dan demografi, data ketenagakerjaan dan data sarana prasarana yang dimiliki puskesmas (Putri, 2019).

Tujuan umum dari Sistem Pencatatan dan Pelaporan Terpadu Puskesmas (SP2TP) ini ialah data dan informasi yang akurat tepat waktu dan mutakhir secara periodik dan teratur pengolahan program kesehatan masyarakat melalui puskesmas di berbagai tingkat administrasi. Adapun tujuan khususnya ialah (Putri, 2019):

a. Tersedianya data secara akurat yang meliputi segala aspek.

b. Terlaksananya pelaporan yang secara teratur diberbagai jenjang administrasi sesuai dengan prosedur yang berlaku.

c. Dapat digunakan sebagai alat pengambilan keputusan dalam rangka pengelolaan rencana dalam bidang program kesehatan.

Pelaporan terpadu Puskesmas menggunakan tahun kalender yaitu dari bulan Januari sampai dengan Desember dalam tahun yang sama. Adapun formulir Laporan yang digunakan untuk kegiatan SP2TP adalah:

1. Laporan Bulanan

a. LB1 berisi laopran data kesakitan

b. LB2 berisi data obat-obatan

c. LB 3 berisi laporan gizi, KIA, imunisasi dan pengamatan penyakit menular

d. LB4 berisi laporan dan kegiatan puskesmas

2. Laporan Sentinel

a. Laporan bulan sentinel (LB 1S) Laporan yang memuat data penderita penyakit yang dapat dicegah dengan imunisasi (PD31), penyakit infeksi saluran pernafasan akut (ISPA). Dan diare, menurut umur dan status imunisasi. Puskesmas yang memuat LB 1S adalah puskesmas yang ditunjuk yaitu satu puskesmas dari setiap kab/kota dengan 
periode laporan bulan serta dilaporkan ke dinas kesehatan kab/kota, Dinas kesehatan provinsi dan pusat (Ditjen PPM dan PLP).

b. Laporan bulanan sentinel (LB 2S) Dalam laporan ini memuat data KIA, gizi, tetanus neonatorum, dan penyakit akibat kerja. Laporan bulanan sentinel hanya diperuntukkan bagi puskesmas rawat inap. Laporan ini dilaporkan ke dinas kesehatan

Data rekam medis di Puskesmas Kejaksan Cirebon digunakan untuk Laporan Bulanan 1 (LB1) tentang data kesakitan, Laporan Bulanan 3 (LB3) tentang KIA atau KIB dan Laporan Bulanan 4 (LB4) tentang kegiatan Puskesmas.

Tabel 1. Penggunaan Data Rekam Medis di Puskesmas Kejaksan

\begin{tabular}{|c|c|}
\hline $\begin{array}{c}\text { Jenis } \\
\text { Laporan }\end{array}$ & $\begin{array}{c}\text { Data Rekam Medis yang } \\
\text { dimanfaatkan }\end{array}$ \\
\hline LB1 & $\begin{array}{ll}\text { 1. } & \text { Diagnosis } \\
\text { 2. Jenis Kelamin } \\
\text { 3. Jenis Kasus } \\
\text { 4. Jenis Asuransi } \\
\text { 5. Nama identitas lain dari sarana } \\
\text { kesehatan } \\
\text { 6. Tanggal Lahir } \\
\text { 7. Waktu dan tanggal pendaftaran }\end{array}$ \\
\hline LB3 & $\begin{array}{ll}\text { 1. Jenis Kelamin } \\
\text { 2. Anamnesis } \\
\text { 3. Diagnosis } \\
\text { 4. Jenis Asuransi } \\
\text { 5. Waktu dan tanggal pendaftaran } \\
\text { 6. Nama identitas lain dari sarana } \\
\text { kesehatan }\end{array}$ \\
\hline LB4 & $\begin{array}{l}\text { 1. Jenis Kelamin } \\
\text { 2. Jenis Asuransi } \\
\text { 3. Jenis Kunjungan } \\
\text { 4. Tanggal Lahir } \\
\text { 5. Nama identitas lain dari sarana } \\
\text { kesehatan } \\
\text { 6. Anamnesis } \\
\text { 7. Waktu dan tanggal pendaftaran }\end{array}$ \\
\hline
\end{tabular}

Data rekam medis di Puskesmas digunakan untuk: ${ }^{4}$

\section{Laporan Bulanan 1 (LB1)}

Laporan Bulanan 1 (LB1) merupakan laporan yang berisikan laporan bulanan data kesakitan. Data rekam medis yang di manfaatkan untuk LB1 adalah diagnosis pasien, jenis kelamin, jenis kasus, jenis asuransi, tanggal lahir pasien, nama identitas lain dari sarana kesehatan, serta waktu dan tanggal pendaftaran. LB1 dilaporkan ke Dinas Kesehatan Kota
Cirebon maksimal tanggal 5 pada bulan berikutnya.

\section{Laporan Bulanan 3 (LB3)}

Laporan Bulanan 3 (LB3) merupakan laporan yang berisikan laporan bulanan KIA atau KIB. Data rekam medis yang di manfaatkan untuk LB3 adalah jenis kelamin, anamnesis, diagnosis, jenis asuransi, nama identitas lain dari sarana kesehatan, serta waktu dan tanggal pendaftaran. LB3 dilaporkan ke Dinas Kesehatan Kota Cirebon maksimal tanggal 5 pada bulan berikutnya.

\section{Laporan Bulanan 4 (LB4)}

Laporan Bulanan 4 (LB4) merupakan laporan yang berisikan laporan bulanan kegiatan Puskesmas meliputi data sasaran untuk ibu hamil, bayi, dan anak-anak, jumlah pengunjung puskesmas, jumlah kunjungan rawat jalan, rawat inap, dan UKGS, upaya kesehatan gigi, mata, lingkungan dan sekolah, serta kegiatan penyuluhan, laboratorium dan tranfusi darah. Data rekam medis yang di manfaatkan untuk LB4 adalah jenis kelamin, jenis asuransi, jenis kunjungan, tanggal lahir, anamnesis, nama identitas lain dari sarana kesehatan, serta waktu dan tanggal pendaftaran. LB4 dilaporkan ke Dinas Kesehatan Kota Cirebon maksimal tanggal 5 pada bulan berikutnya.

\section{SIMPULAN}

Data rekam medis meliputi data administratif dan data klinis. Jenis laporan yang ada di puskesmas terdiri dari data rutin dan tidak rutin. Data rutin meliputi laporan mingguan, bulanan dan tahunan. Data tidak rutin meliputi laporan kejadian luar biasa dan laporan khusus sentinel. Pemanfaatan data rekam medis digunakan untuk laporan bulanan, yaitu LB1 (laporan data kesakitan, LB3 (tentang KIA dan $\mathrm{KB})$ serta LB4 (tentang kegiatan puskesmas).

\section{SARAN}

Lebih memanfaatkan lagi data rekam
medis untuk pelaporan karena belum dimanfaatkan secara maksimal. Data demografi dalam catatan rekam medis dapat digunakan untuk dilakukan analisis pemetaan penyakit

\section{DAFTAR RUJUKAN}

Anita B, H. Febriawati, dan Yandrizal. 2019. Puskesmas dan Jaminan Kesehatan 
Nasional. Edisi 1. Grup Penerbitan CV Budi Utama. Yogjakarta.

Anshori M, dan S. Iswati. 2017. Metodologi Penelitian Kuantitatif. Edisi 1. Airlangga University Press. Surabaya.

Budi, S.C. 2011. Manajemen Unit Rekam Medis. Edisi 1. Quantum Sinergis Media. Yogyakarta.

Gunarti R, dan M. Muchtar. 2019. Rekam Medis dan Informasi Kesehatan. Edisi 1. Thema Publishing. Yogyakarta.

Hatta, G.R. (2014) Pedoman Manajemen Informasi Kesehatan di Sarana Pelayanan Kesehatan. Edisi revisi 2. UI-Press. Jakarta.

Hermawan, I. 2019. Metodologi Penelitian Pendidikan Kuantitatif, Kualitatif dan Mixed Methode. Edisi 1. Hidayatul Quran. Kuningan.
Indradi, S.R. 2017. Rekam Medis. Universitas Terbuka. Tangerang Selatan.

Noor, J. 2017. Metodologi Penelitian: Skripsi, Tesis, Disertasi, dan Karya Ilmiah. Edisi 1. Kencana. Jakarta.

Peraturan Menteri Kesehatan RI Nomor 269 tentang Rekam Medis.

Peraturan Menteri Kesehatan RI. Nomor 75 tahun 2014 tentang Pusat Kesehatan Masyarakat.

Peraturan Menteri Kesehatan RI. Nomor 31 tahun 2019 tentang Sistem Informasi Puskesmas.

Putri S.I, dan P.S. Akbar. 2019. Sistem Informasi Kesehatan. Edisi 1. Uwais Inspirasi Indonesia. Jawa Timur. 